\title{
AN INVESTIGATION OF OYSTER PROPAGATION IN RICHMOND BAY, P.E.I., DURING 1915.
}

\author{
BY JULIUS NELSON, PH.D., BIOLOGIST. \\ New Jersey Agricultural Experiment Station.
}

At the re-pest of the Biological Board of Canada, the writer, during August, 1915, turned aside from his oyster studies in New Jersey waters to investigate the oyster situation in Richmond bay, Prince Edward Island. A study of a region so remote from a locality hitherto familiar, gave promise of furnishing data that would help in distinguishing between local and "essential" influences in oyster propagation.

The ultimate object of these studies is the promotion of the oyster industry, both as a fishery and as oyster culture. It is an effort to conserve and to increase food resources, creditable alike in those who investigate, those who direct, and all who in any way encourage such researches.

\section{PART I.-GENERAL PRINCIPLES OF OYSTER CONSERVATION AS APPLICABLE TO CANADA.}

The oyster-bearing waters of Eastern Canada are practically confined to those bays of the gulf of St. Lawrence that indent the coast of Prince Edward Island, and the adjacent shores to the south and west, viz., Cape Breton and the province of New Brunswick. Farther south, the coast is now practically barren of living oyster beds for a thousand miles, i.e., along southwestern Nova Scotia, the bay of Fundy, and the gulf of Maine practically in its entire extent to Cape Cod. That this coast was once prolific in oysters, though more sporadically than further south, is shown by the existence of oyster reefs recently fossilized, of ancient shell-heaps and by the traditions of colonial and more recent history. It is of both practical and theoretical interest to ask, "What caused the extinction of these oyster beds?" On the true answer to this question hangs our conclusion as to the fate of the Canadian oyster industry.

One of the older ${ }^{1}$ answers to this question assigned the cause of extinction of oyster beds along these northern coasts, to the gradual rising (geologically) of the shores, thus finally bringing the oysters so near to the surface that they were killed by wintry frosts and ice. It may be surmised that, if this process continued, the utter extinction of the Canadian oyster beds might be the ultimate outcome. It appears, however, that the coast is actually sinking; but the oyster reefs have been growing upward somewhat faster having attained a thickness of over 20 feet and have reached as near to the surface as possible. If proximity to the surface limits the growth of an oyster bed, the sinking of the coast has tended to prolong the life of the bed. It is difficult to see how either of these conditions can extinguish the life on an oyster bed, since a limit of height is ultimately attained, where there is a balance between recuperative and destructive forces. Everywhere, the tendency of oyster beds is to grow as high as possible. In the south, the oyster reefs are exposed at low tide; the oysters cannot feed while uncovered, yet the oysters are not starved out. But if the coast should rise, the living surface of such reefs would be killed, while the oysters at the edges would gradually spread into deeper water. On the other hand, the sinking of the bottom would. be highly favourable to oyster growth, provided that temperature and salinity conditions

\footnotetext{
1 Ingersoll's Report on the Oyster Industry, 1882, Tenth Census of U. S., p. $: 5$. $38 \mathrm{a}-4 \frac{1}{2}$ 
were not utterly transformed so as to pass beyond favourable limits. If the northern coast has been sinking, it is possible that this has perm:tted cold arctic currents to enter some of the bays, or to influence the adjacent water that enters on the tides, so that the temperature necessary for summer propagation $\left(68^{\circ} \mathrm{F}\right.$.) is not attained. The extensive shallow flats of Richmond bay and other noted oyster-producing bays of the gulf of St. Lawrence offer the conditions favourable to the warming of the water to the point needed for propagation.

As regards salinity, we know that oysters flourish best when situated where there is a tidal increase and decrease in the salinity of the water; but oysters do grow in waters of very different degrees of saltness, and also in places where there is remarkable uniformity in density. While too much emphasis has been laid on this factor, yet it remains highly desirable that further study be made of the relation of salinity to oyster feeding; but temperature, oxygen, and currents are of much greater significance in oyster growth and propagation.

A study of the temperature of the waters where oysters are now extinct would discover the cause of their extinction. From the tables of temperature ${ }^{1}$ determined by Professor Copeland for Passamaquoddy bay, it is evident that oysters can not propagate in those waters; but there is less evidence that oysters flourished there in early times than for some of the bays of Maine. Even in Prince Edward Island there are fossil oyster beds in the vicinity of living beds; thus we conclude that there must be also other causes for the extinction of oyster life.

In respect to frost, it is remarkable to what extent oysters survive exposure to freezing, when partially imbedded in mud and thawed out gradually. It is asserted that where the water is so shallow that the ice rests on the bottom, at low tide, the oysters are killed by the pressure, unless they lie on a soft bottom, where, however, they are in danger of being buried. On the other hand, a heavy fall of snow before ice forms, clogs up shallow waters and kills oysters and even clams, according to the testimony of intelligent and experienced oyster planters. The effect of melting ice, and especially snow, upon animal life has yet to be studied in a scientific manner.

We are confronted with two opposing influences. Shallow waters, especially when so free from grass as to be swept by currents, favour oyster propagation in the summer, but are most unfavourable to oyster life in winter. Just here is a situation that can be advantageously handled by the art of man, so as to greatly improve upon nature; for the young oysters produced on the flats can be moved to deeper water on the approach of winter. This is never done under the conditions of a free or public fishery. It is in the interest of conservation that oyster farming be introduced to supplement natural production. The foremost difficulty encountered in this connection is not our inexperience and our ignorance of the proper way to raise oysters, so much as the opposition of those who believe in harvesting what nature produces without contributing the labour of cultivation. It takes many years of education and the observation of the increased harvest resulting from oyster farming, as well. as the annually decreasing product secured by free fishing, to teach the oyster fishermen that it is to their interest as well as that of the general public, to promote scientific oyster culture.

Man has been the oyster's greatest enemy; although, if he will use remedial measures, he can more than counteract the destruction. It is supposed that the disappearance in recent historic times of some of the natural oyster beds is due in large degree to the increased amount of sediment carried into bays by rivers, on which saw-mills have been erected, or whose drainage areas have been cleared and ploughed. Sawdust and sand are the most injurious of the forms of silt; light mud is more readily handled by the ciliary feeding apparatus of the oyster; yet when silt is present as a nearly continuous suspension in the tidal currents, it seriously

1 Contributions to Canadian Biology 1906-10, p. 286, etc. 
interferes with feeding, causing ultimate starvation. Silt that settles may be abundant enough to bury oysters; but even an exceedingly thin layer deposited on the objects used as cultch by the spat, will prevent fixation and therefore to the same degree prevent propagation. Assuming the spat to have secured fixation, it takes proportionately less silt to smother these delicate tiny oysters, than will bury the adults.

The main cause of the destruction of natural oyster beds in historic times has been improper and careless fishing. The history of the oyster industry everywhere has shown that when oyster fishing has been pursued under no other regulations than those born of the wishes of the fishermen themselves, the natural beds were rapidly depleted, and finally exterminated, unless remedial measures were undertaken. Accordingly there have arisen many laws regulating this fishery, that seem strange to those engaged in private farming. For example, oysters may not be taken from natural beds except during the "open season." The "close season," during summer, varies greatly in its limits according to locality, but usually includes May, June, July, and August. Fishing must be confined to the hours between sunrise and sunset. Oysters may be taken with tongs but not with rakes; and dredges may not be used, nor may oysters be taken through the ice. Oysters may not be sold under three inches in length, and those smaller than this must be returned to the beds, etc. These laws are enforced by police methods; and fines and penalties are imposed for a breach of their provisions.

Under private culture each farmer tries to promote his own ultimate best interests, and thus also the public welfare; but those who share in a public fishery consider only their own immediate self-interest. They sacrifice their own future, as well as the public welfare. The oyster laws are a result of an honest and fairly intelligent endeavour to conserve the natural oyster resources, and they undoubtedly partly succeed in effecting their object. It will be instructive to consider for a while the question of the depletion of natural beds and their conservation.

\section{AGENCIES DESTRUCTIVE TO OYSTERS.}

It is a fundamental biological principle that the agencies that destroy the individuals of any living species nearly balance the natural rate of increase; that after a species has established itself in any locality the number of its population remains. nearly the same from year to year, though the balance between birth-rate and deathrate will fluctuate slightly up and down as one or the other set of factors increases or decreases. For instance, if food becomes temporarily more abundant, there is an increase in population, while a decrease in food results in a reduction of individuals, through starvation. So likewise there will be fluctuation due to the prevalence of various enemies and epidemics.

Under this law there must be as many deaths as births; or, vice versa, the number of births must be sufficient to make good the loss by death. Therefore, we can judge of the extent of the destructive forces by simply noting the fecundity of a species. The oyster is one of the most prolific of all creatures. A single large "spawner" has been estimated to produce annually sixty million eggs, but we must remember that half of the oysters are males, and that there are many small oysters. Neglecting the very small "seed" oysters, we may conservatively say that an oyster bed produces from ten to fifteen million young for each adult present; so that, if all lived and there were no further propagation, an oyster bed would be ten million times larger in five years. In spite of this astounding conclusion, however, the oyster beds are being depleted simply from the annual removal of a few hundreds or thousands of barrels. This should be the most convincing proof that the natural foes of oysters are extraordinarily formidable. Then why may we not believe that the destruction caused by man is insignificant in comparison, and so need not be considered to have 
any practical effect? Because "it is the last straw that breaks the camel's back," and because all natural species, including oysters, exist under a 'balance. We have only to refer to the extinction of the American bison, which existed in such huge herds on our plains; or still better, the extinction of the wild pigeon, whose flocks in migration used to darken the skies of nearly a continent for days. It is absurd to believe that this species was hunted until the last pair was shot. The destruction by the hunter, great as it was in the case of the bison, or of the pigeon, was probably sight in comparison with all the other natural enemies, but the latter, suddenly supplemented by man, finally turned the balance, and completed the work after the hunting ceased. Let us consider some of the destructive agencies operating against oysters.

\section{THE MEANING OF FECUNDITY.}

When the oyster ejects its millions of eggs into the water, these at first tend to sink to the bottom, which they would reach in ten minutes in calm water. In order that the eggs may develop, they must be fertilized by the male spawn or sperms. The sperms must be sufficiently abundant to enable an average of three hundred to cling to each egg during the ten minutes the egg is afloat. They must have been recently ejected from the male oyster or they will have died. The male oyster must have been ready to spawn at nearly the same time as the female, and must have lain sufficiently near, so that the water flowing over him shall reach the female by the time she emits her spawn. This is favoured by the fact that the process of spawning usually takes several hours or even days. We need to ascertain a good deal more than we know now before we can make precise statements, but we know that even where water is in such favourable agitation that the eggs are prevented from sinking to the bottom, they must be fertilized within a quarter of an hour to undergo normal development. This is the first reason for the enormous production of eggs. In spite of losses, vast numbers of developing young are started. As many as ten thousand newly hatched oyster fry or larvæ have been counted in a single bucketful of water dipped up over an oyster bed. But this signifies that there are other chances yet to be taken.

\section{COMPETITION WITH PLANKTON ENEMIES.}

After hatching, which occurs in from five to eight hours, the young oyster swims so weakly that the feeblest current_carries it hither and thither. Indeed, all it effects by swimming, is to reach the surface and then to dive again, and so keep going up and down, requiring an hour to swim a distance of a few feet. But the oyster fry find the water is crowded with minute enemies, such as Copepods (water fleas), the "veligers" if the many snails that cover the bottom, and a vast number of the larvæ of bivalves of various species, all capturing everything within reach small enough to enter their hungry maws. These enemies eat the young oysters, and the messmates consume their food. For several weeks the young oyster has to run this gauntlet and obtain sufficient food to effect an increase in volume of a hundredfold before it attains the spat stage in its development. Great as has been the ninefold decimation, yet so many survive that, if clean oyster shells be planted at the time of spatting, as many as a hundred or more spat may be caught upon a single shell almost anywhere upon or near an oyster bed.

\section{LOSS BY TIDES.}

This great survival is the more remarkable when we reflect that twice daily a vast body of water runs over the oyster bed out to sea, carrying myriads of larvæ, and only a part of this water returns. The astonishing fecundity of the parent oysters sufficiently meets this loss also. But the struggle for life has not yet ended. 
THE QUEST FOR CULTCH.

Unless man has placed clean cultch in the water, nature provides only the old shells of dead oysters, mostly buried in mud, or the outsides of the living oysters. These and other exposed shells are more or less covered with slime, silt, and mossy growths of both animal and vegetable nature. Millions of other larvæ also needing cultch, such as "deckers," "jingles," "barnacles," etc., have pre-empted the best places and are busy feeding on every living thing they can swallow. Worst of all, through the open valves of the older oysters and of mussels, clams, etc., currents of water flow, bearing all sorts of plankton, presumably also oyster fry, to be used as food. How small a chance these fry have of escaping and finding a foothold! If they cannot fixate they are doomed to destruction. But vast numbers do find a foothold and do succeed in growing, and crowding each other, and competing with all the other oysters for food. In this struggle the survivors ultimately overgrow and smother the previous generations. Great as is the loss through crowding, it is exceeded by or anticipated by an earlier destruction, sometimes including all the spat on most of the shells.

THE ENEMIES OF GROWING OYSTERS.

The numerous little Nassa snails are constantly exploring the surfaces of shells and scraping off all the newly set spat. Those that escape may reach the size of a fingernail, and then, along comes a boring snail and drills a hole through them, or a crab nips them off, or mud stirred up by storm smothers billions in a day, or the frosts of winter kill them. Later come the starfishes opening the oysters by their patient pull, or bottom fishes may crush them in their paved jaws and throats. Last of all, man comes with tongs, and rakes, and dredges, and takes the few survivors. Thus ends this eventful history. The fisherman then wonders why the Creator doesn't supply new oysters the next season to replace those taken: usually the best answer given to this question is to bow in meek submission to Providence.

\section{CONDITIONS FOR PROPAGATION.}

A little insight into oyster biology should enable any one to see that the production of oysters depends on the co-operation of four conditions, viz: (1) suitable cultch, (2) in waters stocked with a sufficient number of spawning oysters, (3) lying close enough to ensure fertilization of the eggs, (4) on a bed sufficiently extensive to fill the water, over a considerable area, with oyster plankton to such a degree as to overbalance the larval mortality.

When the large oysters, which furnish the bulk of the spawn, are yearly removed, as well as the cultch to which they are attached (including the young oysters attached either to them or to the cultch), then the bed is robbed in three-fold degree, viz., the cultch is decreased, the large spawners become fewer, and the "rising generations" are many times decimated. If the production of spawn is reduced to half, and the available cultch to half, then the production is reduced to a quarter.

When shells, hitherto buried, are uncovered by working on a bed, they become available as cultch, but this advantage is greatly reduced through the fact that much silt is scattered upon the shells by the very operation which exposed them. In oyster fishing, ultimately all the cultch utilized by spat will have been removed, and then we have remaining simply an oyster reef covered by a layer of mud, upon which not an oyster can be produced, even though a current rich in oyster plankton, derived elsewhere, should flow over it at a time when the fry are matured to the sessile stage. Clam production is much simpler, for no cultch is needed. 
STEPS IN CONSERVATION

One of the earliest steps taken in most instances towards the conservation of natural oyster beds has been the enactment of a "cull law." This compels the fisherman to sort his catch on the bed, throwing back the unmarketable material, consisting of shells and small oysters. The main advantage secured is the conservation of a percentage of the seed oysters. The spat attached to the large oysters cannot be removed, while the shells which are returned are largely silted up when spatting time comes. In fact, these shells, unless newly dug out of the mud, require to weather for weeks, exposed to rain, snow, sun, and air before they are suitable for spat collecting.

It is evident that no fisherman would thus care for the shells, unless compelled by law; yet it seems to the writer that it would be a practically enforceable provision, were it embodied in the cull law, particularly if a market for these shells could be secured. Sometimes the State has purchased cultch and placed it on natural beds; but this practice was abandoned for two reasons: the cost of the work was greater than under private enterprise; and the Government felt it was making a gift to a special class. Where oyster farming prevails, the planters would buy this cultch, particularly in those regions, where shells are scarce because no shucking operations are carried on. Now that oyster culture is under way in Canada, the securing of cultch is a matter of great concern. It appears that the most available supply must come from a sorting of the so-called "mussel-mud" dug out of dead oyster reefs. The firmest of these shells, which are often of large size, when washed clean, are good collectors. But no cultch should be planted until spatting has just begun. Happily, scientific oyster research has in recent years enabled us to closely determine this date; but important matters are still to be cleared up.

\section{THE RATE OF PRODUCTION OF A BED.}

The legal restrictions imposed on the fishermen have the object of conserving the natural oyster production. The cull law helps this in a measure. Another prominent legal provision is the "close season" during summer, when no oysters are permitted to be taken, because it is believed that the spawning oysters should not. be disturbed. nor the cultch be littered with silt by fishing operations. This "close season" has been lengthened from time to time, at both ends, by shortening the "open season," in order to reduce the number of oysters taken, it being believed that the bed is unable to supply oysters in quantity equal to the demand. It is doubtful if this provision becomes effective unless made se drastic as to practically deprive the fisherman of his
means of living.

When these enactments fail, more drastic measures are adrocated, such as the closing of the oyster beds for a number of years, until nature has had time to restore them. But such legislation is founded on a failure to grasp a fundamental principle, to wit, a depleted oyster bed will be restored at a rate dependent on the percentage of available cultch multiplied into the available spat. Assuming that there are still enough oysters remaining to produce a fair abundance of spat, and that there are plantings of cultch on the bed at the proper times, then it will take five years for the bed to reach its acme. Then if this bed were henceforth left undisturbed by man, the forces of destruction and of natural production would just balance. On the other hand, suppose there was no planting of cultch, then, under nature, a depleted bed would take an indefinitely longer time to reach its original condition. In any event, after such a bed has reached the point of highest production, a survey of its extent and examination of an average square jard or rod, will enable one to calculate just how many bushels of oysters are present. Knowing then the number of bushels that can be taken in the open season, it can easily be reckoned how many years will elapse before the bed again will be reduced to a point where the fishermen can not secure their average catch. It should be evident that under artificial culture the 


\section{SESSIONAL PAPER No. 38a}

ranks of the oysters are restored by fresh cultch, under whatever rate the adults are removed, so long as the remaining oysters furnish sufficient spat. In case a 5 yearold oyster is marketed, then, without culture, if so large a proportion as a fifth of the product on the bed be taken each year, nature would not be able to replace this completely, for reasons already explained. Yet the demand on the restored bed might be so great that half of the oysters would be removed one year, two-thirds of the remainder the next, plus any natural increase, and so on. Thus the old story of gradual depletion would be repeated. For the first two years after a bed is opened, the production would be double or treble what it was before the bed was closed, but it soon drops back to the small figures. Now, calculating that there is no harvesting for the five years during which the bed has been closed, and suppose that in five years it must be closed again, we see that in the course of ten years the average yearly product is equal to the minimum harvest. There is no gain in production, and the only advantage is the saving of the oyster bed-a bed greatly depleted and not yielding its full capacity. The fact is, that a natural bed yields the highest food production when all the oysters above a certain size are removed annually, and an equivalent of cultch is added. But such a bed gives the highest possible yield of oysters if it is used solely as a propagating bed, the seed being sold to oyster planters to mature for market on ground that could not be used for propagation. This is an important matter, and we need to go into it from the point of view of scientific oyster culture.

\section{EFficient Use of Oyster Ground.}

Suitable localities for propagation and growth may in general be occupied by (1) natural beds, (2) under artificial oyster culture a certain additional area used for propagation and growth, and (3) an additional area for growth only, and (4) in a still further area, oysters might live for a while without growth. Area No. 4 is useful for storage only; Nos. 1 and 2 are so nearly alike, biologically, that fishermen have contended, sometimes successfully, that they are alike legally, so that farmers who had made such areas productive, were robbed of the fruits of their labour. When we realize that area No. 2 would be barren but for the labour of man, we must justly conclude that from a legal point of view they are radically different from natural beds, however much they may resemble them biologically.

Assuming that a farmer owns only areas like No. 3, then he cannot produce his own oyster seed, and must secure it in various degrees of development, from either the fishermen who harvest No. 1 or from farmers who own areas No. 2. His problem becomes this: Which ventures bring the best returns, the purchase and cultivation of oyster seed requiring one, or two, or three, or four years, to mature for market? If there is a law preventing the fishermen from removing oysters under marketable size from natural beds, then the farmer of No. 3 is dependent on what he can secure from the cultivators of No. 2.

Let us next consider the culture of ground No. 2. As this is suitable for propagation, the owner can catch his own seed and is thus independent of the public beds. His ground is also suitable for growth, and so his problem is to find out which pays better, either to keep the seed. on the ground where caught, until it is marketable, or to sell it at the age of one, two, or three, or four years, to owners of No. 3. In the former case, his farm will resemble a public bed, biologically speaking, but he can handle the situation to his own best interests, with his best judgment, and not under the restrictions pertaining to public fishing. He will remove each year the right number of marketable oysters, replacing them at the proper time by fresh cultch. $\mathrm{He}$ may do better: he may divide his ground into five plots-a, $b, c, d, e$. Let $a$ represent the plot that catches the best set of spat. Each year, for four years, he will remove all the spat from $a$ and plant them successively upon $b, c, d$, e, respectively, reshelling $a$ at the proper times. He gets no pecuniary returis until the fifth 
year, when he markets the entire crop on $b$. In case there has been annual spatting on this ground, he culls off the immature oysters and places them, not on $c$ but on the plots where oysters of similar ages are found. Thus $c$ is cleared to receive the next crop that is raised on $a$.

From thence on, he has an annual income, harvesting one of his plots yearly and replanting from his seed-raising ground.

We have gone into this detail with a purpose. This method of farming is the highest form of specialization, and should give the highest possible returns. Now please note well: each year the farmer harvests only one-fifth of his farm, and onefifth of his growing crops. If he kept the entire farm like a natural bed, taking off an annual crop from the whole area, it is evident he could not do so well because all the generations would be intermixed and competing on those parts where there was most propagation, and on other parts less favourably situated, the propagation would not be at the maximum rate, but at a rate that would greatly reduce the annual product of marketable oysters. At the very best, he could not harvest as much as a fifth of his crop, and he would have to use better methods than those now in use on the natural beds, to keep his oyster bed from depletion.

Oyster farming resembles truck gardening in some respects, but differs in needing several years to mature the crop. On a mixed bed, the best returns come from removing annually as many oysters as can be spared, and not by introducing a system of open and close seasons. It is evident that what is good treatment for a mixed bed under private ownership, will be best for a similar bed under public ownership. There can be but one conclusion here, viz., that if natural beds are to be conserved, they should be under the supervision of an expert, and should receive plantings of cultch at the proper times. The expert must determine just how many oysters may be annually removed.

\section{THE FATE OF DEPLETED BEDS.}

Under a system of private oyster culture, it is necessary for planters who have little or no propagating ground to obtain their seed from natural beds. This leads to an abrogation of the prohibitions against taking immature oysters. Then the fishermen will market their catch at home, for planting in waters more or less adjacent to the public beds. The inevitable result will be to render the latter as barren as possible. When both cultch and oysters are gone, the bed is extinguished. But in this case, if cultch be placed on the bed it is as productive as ever, up to the limit of the supply of cultch. This is due to the fact that the oysters which have been removed are still growing and spawning in neighbouring waters, so that a supply of spat is brought to the old grounds. The fishermen will harvest this urop of spat, and sell to the planter, or plant it themselves on their own farms; and history shows they will as zealously guard rights to such beds as they formerly did where they were confined to harvesting mature oysters only. As no one puts cultch on such beds, it is plain that however much spat may be present in the water derived from the private grounds, the beds will last only as long as the cultch naturally present will last, and that the production will be only as much as the available percentage of cultch present. Inevitably such beds become "barren" bottoms and open to leasing. There can be only one way of escape, and that is for the fishermen to form a co-operative society to work the public beds under a mutual agreement.

But this, of course, cannot be done, because others of the public than the fishermen, are also owners. Fishermen have been offered first chance in taking out leases of what they considered to be public ground, and have refused because they know that if once this right is granted, all or nearly all of the public grounds will ultimately come into the ownership of capitalists. So here we have a special phase of the old struggle between capital and labour. It is not our purpose to more than touch on the skirts of the matter that is political rather than biological, but still is vitally involved in any scheme of oyster conservation. 
THE LEGAL SIDE.

Experience has shown but one successful way of developing oyster resources, and that is the encouragement of oyster farming. The introduction of oyster culture has always met with opposition from the public fishermen, and such opposition has had a degree of justification. Usually it has been so mingled with prejudice and shortsightedness, that the sympathy of the general public has been estranged. Theoretically, the best interests of the whole public require that the oyster industry should be conducted wholly by methods that have proved successful in private farming-letting private judgment manage business operations, rather than a code of regulations. Practically, however, the best course to follow is to recognize the existence of public beds, and public fishing rights. Such rights and beds should be carefully defined, and the boundaries of public beds marked in a clear and simple manner, even though some harren bottoms should be included. Only by extreme or radical measures can natural oyster beds be preserved. But where oyster culture is successful there is less necessity for conserving such beds. The public oystermen have endured a surprising amount of restrictive legislation, supposed to be as much for their interest as that of the public. Under our larger view of the oyster question, the fishermen might be given more freedom and influence in shaping the regulations for the use of the public beds. Restrictions should primarily have in view the protection and encouragement of oyster culture, in which the real public interests inheres. Efforts should be made to secure impartial justice for all. A mutual obligation rests on both fishermen and farmers, to respect each others' rights. Those who wish to frame the wisest laws, seeking for harmonious co-operation between these conflicting interests, are advised to study the history of oyster legislation in as many states and countries as possible. There will be found a variety in details, resting on local conditions, and a similarity in general principles, resting on biological grounds.

THE DECLINE IN THE CANADIAN OYSTER PRODUCTION.

That oyster production in Canada, and particularly in Prince Edward Island, has steadily been decreasing is evident from statistics. See "Table showing the aggregate quantities of oysters caught in the Dominion since 1876, compiled from annual reports of the Department of Fisheries," given on page 47 in the report of the Dominion Shellfish Fishery Commission, 1912-13. In this table we note a curious back-and-forth fluctuation from year to year; but if the entire series of years be divided into five-year periods, and the annual product be averaged for each five-year period, or semidecade, the annual catch in barrels is as follows:-

\begin{tabular}{|c|c|c|c|c|c|}
\hline Periods. & Years. & $\begin{array}{c}\text { New } \\
\text { Brunswick. }\end{array}$ & $\begin{array}{c}\text { Nova } \\
\text { Scotia. }\end{array}$ & $\begin{array}{l}\text { Prince } \\
\text { Edward } \\
\text { Island. }\end{array}$ & $\begin{array}{l}\text { Proportion } \\
\text { for P.E.I. } \\
\text { Per cent of } \\
\text { whole. }\end{array}$ \\
\hline 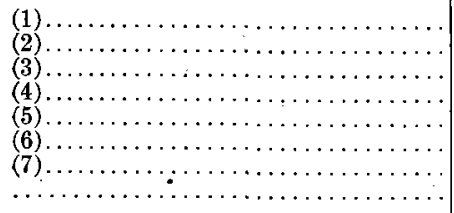 & $\begin{array}{l}1876-1880 \\
1881-1885 \\
1886-1890 \\
1891-1895 \\
1896-1900 \\
1901-1905 \\
1906-1910 \\
1911-1912\end{array}$ & $\begin{array}{r}9,724 \\
12,765 \\
20,426 \\
17,434 \\
18,740 \\
12,854 \\
16,564 \\
15,436\end{array}$ & $\begin{array}{l}1,172 \\
1,652 \\
2,049 \\
3,327 \\
2,150 \\
1,517 \\
1,597 \\
2,090\end{array}$ & $\begin{array}{c}17,020 \\
34,644 \\
36,379 \\
30,622 \\
22,735 \\
19,860 \\
10,583^{*} \\
8,835\end{array}$ & $\begin{array}{l}60 \\
70 \\
60 \\
60 \\
50 \\
60 \\
30 \\
35\end{array}$ \\
\hline
\end{tabular}

* For 1907-8, the quantity credited to Prince Edward Lsland was only 1,672 barrels. Leaving that year out, the average for the remaining four years becomes 12,811 barrels, which is 40 per cent of the average total credited to the Dominion for the same period. 
7 GEORGE $V$, A. 1917

The third period shows a maximum of oyster production in the Dominion, and also in the two main oyster-producing provinces. The decline began in the middle of the fourth period, mainly in Prince Edward Island, which led in production up to 1906, when it sank to the level of New Brunswck. Thenceforth it fell behind until its production reached only half of the province of New Brunswick. The decline in the latter province from the maximum has been little more than 20 per cent with 80 per cent decline in the island province. This difference in the rate of depletion has been explained as due to two main influences: the greater demand for the island product and the discovery of new beds in New Brunswick, when several of the older beds were fished out.

It is interesting to read the summary of the reports of various inspectors and experts from 1868 onward, given in Ernest Kemp's "The Oyster Fisheries of Canada," 1899. These reports sound a uniform warning that the Canadian oyster industry was in danger of complete destruction unless proper measures were taken to conserve it. The decline in the industry has not been so keenly realized by the fishermen, because the price of oysters has increased proportionately. This fact augurs seriously for this industry. Oysters, even when cheap, are considered somewhat of a luxury, and a rise in price must tend to exclude them more and more from the menus of the middle classes; while at the same time the importation of foreign oysters must increase. The Canadian fisherman has relied for the protection of his interests on the superior quality of his oysters; but this superiority is threatened in two ways: first, it has become necessary to market oysters from beds that do not produce them of the highest quality; and second, by the attempt of planters to grow imported seed in Canadian waters, in the hope that they will attain the citizenship at least, or, if possible, attain the quality of the home product. This "American" seed is sometimes of inferior quality and, although it certainly improves under cultivation in more southern waters, it lies dormant for a long time, without growth, when transplanted to the northern beds. According to the claims of the fishermen, with whose product these oysters compete, when sold, it injures their market by giving the oysters from their locality a bad reputation.

The cultivation of foreign oysters in Canadian waters is of considerable scientific as well as practical interest. From the slight evidence at hand, we conclude it will take more than a year to acclimate Connecticut seed in Canada, before growth begins. It will take a correspondingly longer time to impress the Canadian quality upon these oysters after growth begins. It will, therefore, be wise to import this seed as young as possible to secure the best results. It is still somewhat doubtful whether the Canadian oyster may not be a distinct variety, breeding true to its kind. The Canadian oyster spat, at the time of fixation to cultch, is a fourth larger than the spat in the corresponding stage of development in New Jersey waters. Whether this difference is due to environment or is inherent, remains to be settled by experimental observations. Oysters usually show improved quality in colder waters, due largely to the shortness of the spawning season. While it is interesting to note the outcome of attempts to cultivate "American" oysters in Canada, it will be wisest for the Canadian planter to do all he can to promote the production of the native seed.

\section{PART II.-OYSTER PROPAGATION SURVEY OF RICHMOND BAY, P.E.I.}

In presenting the following synopsis of observations made in Richmond bay we wish to call attention to the fact that there are many points in the life and habits of oysters and their young that are yet unknown and which should be known in order to make the proper applications to economic problems. Aiming to make our investigations throw. light upon these other matters, at the same time that we attempt to be as practical as possible, the work of surveying so extensive an area as that of Richmond bay by the methods developed by our previous experience, introduces much complexity. There were so many things that should receive simultaneous attention that much was 


\section{SESSIONAL PAPER No. 38a}

crowded out or missed, which demands a more specialized investigation. Lacking previous familiarity with this considerable expanse of water, it seemed best to get as broad a view as possible of the conditions, from which departure could be made in any special direction, as the findings might suggest.

\section{DESCRIPTION OF METHODS.}

The most important procedure is the determination of the oyster "plankton," i.e., the young "fry" in the water, which furnishes the "setting" of "spat." This study was prosecuted by the use of a net made from the finest bolting silk. Counting out Sundays and stormy days, plankton studies were made on eighteen days, at an average rate of fifteen per dav and a maximum of more than twice that figure. The net gathers a vast number of many kinds of larva--bivalves, univalves, water fleas, etc., and as it is necessary to sort the oyster larvæ out from each sample, under a microscope, and count and measure them, the work is nervously strenuous and timesonsuming.

Our procedure consisted in straining approximately known quantities of water through the plankton net, and then to "wash" the "catches" into a series of widemouthed bottles containing sufficient formalin to kill the larvæ, so that they would all settle to the bottom. After a number of such samples were collected, the boat was run into the nearest. quiet harbour, where the sediment in the bottles was examined in partial lots, until the entire amount in each bottle had been sorted by the methods developed in our previous researches.

The samples were collected in the following ways:-

(1) Dipping water in the net while the boat was under full headway, the average rate was two samples per mile, each of 20 quarts of water.

(2) Dragging the net back and forth by hand a definite distance and number of times while the boat was stopped. This is called "swinging" the net.

(3) Towing a definite length of time, say a minute under reduced speed.

(4) By means of a cylinder, devised with valves for this purpose, into which the net was fitted, we secured samples at definite depths, or determined the vertical distribution of the fry by lifting the net through a fixed distance, a definite number of times.

We thus endeavoured to make our determinations quantitative as well as qualitative in character. The point from which we set out each morning, and to which we returned each evening was Malpeque wharf. We were farthest from home each day at noon, and samples were taken as opportunity offered on the return route as well. We are desirous at this point of the narrative to express our thanks and hearty appreciation for the kindly courtesies extended by Prof. A. D. Robertson, the use of whose boats and other equipment we shared, doubtless at times at a sacrifice of his convenience, at least, he being engaged in studying oyster growth.

\section{LOCALITIES EXAMINED.}

For purposes of location and orientation, the following descripton of Richmond bay is given: This bay is a considerable southward indentation from the gulf of St. Lawrence, of the north shore of Prince Edward Island. The coast at this point trends northwest, thus the western shore of the bay is one and a half times longer than its eastern. A sandbar 10 miles long separates the bay from the gulf, and limits its outlet to a channel a mile wide situated at the northern terminus (cape Aylesbury) of the eastern shore. Each shore has three considerable indentations. On the east, most northerly is Darnley basin, next comes Shipyard basin, and at the head of the bay is Chichester cove. On the west, situated correspondingly are Bideford river, Grand river, and Bentinck cove. 
Confining one's attention to the channel or deeper parts of the bay, the tide entering north of cape Aylesbury sends a small branch southward into Darnley basin. The main portion flows west at the southern end of the bar between Royalty point and "Fish" island. Three miles west from Aylesbury the tide strikes Horseshoe shoals and spreads thence in three directions: (1) northwestward for 4 miles to enter the mouth of Bideford river, between $\mathrm{Hog}$ island and Bird island on the east and Gilles point on the west; (2) the southwestward tide flows 2 miles to "Ram" island shoals where it bends south and southeast around Ram island on a 6 mile course into "March water," and eastward into Shipyard basin, to Malpeque wharf; (3) the central portion of the tide on Horseshoe shoals continues westward for $3 \frac{1}{2}$ miles to North Bunbury shoals. Part of it continues on for 5 miles farther, passing north of Charles point to reach Grand river. The main portion of the tide, 3 miles wide, turns south between Charles point and Bunbury island. Four miles to the south it runs between Beech point on the east and Bentinck point on the west, and enters the head of the bay, where it ends in three divisions, viz., Bentinck cove on the west, Chichester cove on the east, and Webber cove, with Barbara Weit river on the south, 8 miles from North Bunbury shoals.

Apart from its estuaries, Richmond bay may be conveniently divided into: (1) an outer section or Lower bay, lying east of a line drawn from Ram island northward to Hog island, but this line should curve westward far enough at its middle, to include all of Horseshoe shoals; (2) an inner section or "Upper bay," lying south of a line drawn due west from Beech point to the cliffs north of Bentinck point; (3) a middle section, between the other two, that we may designate as the "Central portion." The southern half of this section is split into two by Curtain Islands shoals, which extend nearly 4 miles northwestward from Beech point. Bunbury island, situated near the northern extremity of these shoals, marks closely the geographical centre of the bay. We shall confine the term "Central bay" to the portion north of Bunbury. The part west of the shoals, from its shape may be called the "quadrangle," that to the east is "March water." The Upper bay empties mainly into the "quadrangle," but some water flows over the shoals into March water, which in turn also partly spills over Ram Island shoals into the Lower bay. The "Central bay" receives the Bideford from the north, Grand river from the west, the quadrangle from the south, and March water from the southeast, between Bunbury and Ram islands. We shall consider successively the data secured from a study of the different localities. Most attention was given Grand river and March water; the data from other localities are fragmentary.

\section{BIDEFORD RIVER.}

This river from the head of navigation to Gilles point is 6 miles long. Trout river enters it in the south, and a strait called the narrows, lying between Lennox island and the mainland, enters from the north. The lower part of the river is bounded on the northeast by Lennox and Bird islands, and it empties into the Central bay in conjunction with the waters of a large shallow lagoon that lies east of Lennox and Bird islands and west of the sandbar. The southern end of this lagoon is bounded by Hog island, near which are oyster beds that owe their existence to the influence of the adjacent flats, in warming the ebb tides.

At the northern end of the widest part of the Narrows, on August 6, a few oyster fry were found in 20 quarts of water of 1,021 density, $70^{\circ} \mathrm{F}$, , the largest being 160 microns ${ }^{1}$ in diameter.

At head of navigation in Trout river, August 17, during rain, high water was 1015 at $72^{\circ} \mathrm{F}$. Vertical sampling of different parts of the river yielded oyster fry of 160 microns to 400 microns, at the rate of one per 15 to 60 feet.

1 Twenty-five thousand microns equal one inch. Oyster fry are first seen at 60 microns ană "set" as spat when they are from 320 to 400 microns in diameter. 


\section{SESSIONAL PAPER No. 38a}

At the head of Upper Bideford, August 6, low water was 1019.5 at $74^{\circ}$ F. Four samplings, each of 20 quarts, along its course to Trout river, yielded seven fry of 160 microns, and a few at 100 .

Between Trout river and the Narrows, August 6, in water of 1019.5 at $72^{\circ} \mathrm{F}$, large fry were present at the rate of one per 30 quarts. August 17, fry were found of sizes 120,180 to 260,360 to 380 microns, at the rate of one per 60 feet vertical, which means that in water 30 feet deep, ten hauls from bottom to top would yield five large fry.

In the section off south end of Lennox island, August 6, water was 1020 at $70^{\circ} \mathrm{F}$., and only one large fry and a few small ones appeared. On August 17,1019 at $70^{\circ} \mathrm{F}$., three samples gave twelve fry from 160 to 400 microns, most being 240 microns.

In the section along Bird island, August 6, only few fry present, and less than 120 microns in size. On August 17, water sample 1020 at $70^{\circ} \mathrm{F}$., gave one fry of 200 microns.

Central bay, adjacent to Bideford river, August 6, 1021 at $70^{\circ} \mathrm{F}$., fry less than 110 microns. August 17, near low point, one fry 180 microns, one 240 microns.

\section{GRAND RIVER.}

From the bridge to the ferry is a distance of 4 miles, and from the ferry to Charles point is 3 miles. The latter section, 2 miles wide, is more a cove than a river. From the bridge to Southwest creek is nearly a mile, thence to Cross creek nearly two, and thence to the ferry is a mile and a half. About half a mile below the ferry at Black point the river empties into its cove.

Section below the bridge, August 6, flow, 1018 at 72 F.; August 14, ebb, 1018.5 at $74^{\circ} \mathrm{F}$. Vertical samples gave one fry per 20 feet, sizes $120,160,320,360$ microns nearly equally abundant. August 20, flow, successively 1018 at $66 \mathrm{~F}$. and $68 \mathrm{~F}$., 1017 at $67 \mathrm{~F}$., and farthest from bridge 1019 at $68 \mathrm{~F}$.; very little but sand in four samples. Samples on higher water gave one per 4.0 feet vertical, one per 10 quarts, four per minute towing, 80 to 200 microns. August 25, strong ebb, one fry per 6 feet of towing, from 120 to 320 microns, majority 240 microns. Towing one minute with large No. 12 net, gave seventy fry, 160 to 340 microns, with maxima at 240 and 320 microns; small fry escape through this net.

Section below Southwest creek, August 14, 1019.5 at $71^{\circ} \mathrm{F}$., fry one per 2 feet vertical; farther down, one per 6 feet, ranging from 200 microns to smaller, most are below $160 \mathrm{mu}^{1}$ Half of oysters dredged are still filled with spawn. August 20, 1018.5 at $68 \mathrm{~F}$., early flood, few fry; but when near high, 1019.5 at $68 \mathrm{~F}$., fry are abundant, one per 6 feet vertical, one per 5 quarts, thirty per minute towing, ranging from 70 $\mathrm{mu}$ to $280 \mathrm{mu}$, mostly below $100 \mathrm{mu}$. Farther down, 1019.5 at $68 \mathrm{~F}$., one fry per 6 feet vertical, one per ten quarts, twelve per minute, 90 to $360 \mathrm{mu}$. August 21, twelve samples, 1018.5 at $70 \mathrm{~F}$., near high, gave one to 40 quarts, up to nearly one per quart, from 9 to 166 per minute, from one in 4 feet vertical, up to one per foot. Sizes run from 80 to $320 \mathrm{mu}$ with four-fifths of them below $110 \mathrm{mu}$, and some at 200, 240, and $320 \mathrm{mu}$. August 25, half ebb, 1020 at $70 \mathrm{~F}$., twenty quarts dipped, give from 9 to 33 fry, also at low 1019 at 74 F., got one fry per 2 feet vertical, and 34 per 160 feet of towing; sizes, 80 to $320 \mathrm{mu}$, majority below $120 \mathrm{mu}$, several at 180, 240, and $280 \mathrm{mu}$. August $28,1019.5$ at $68 \mathrm{~F}$. flow; one fry in 8 . to 15 feet vertical, eleven in 1 minute's tow; sizes, 90 to $380 \mathrm{mu}$, with groups at $100,150,280,320,360 \mathrm{mu}$.

Section above Cross creek, August 14, 1018.5 at $72 \mathrm{~F}$. Oysters dredged here have all spawned, fry abundant, one per 2 feet vertical, ranging from 100 to $200 \mathrm{mu}$, and a few at $360 \mathrm{mu}$. Majority are $160 \mathrm{mu}$, perhaps ten days old. August 20, water low flow, 1018 at $68^{\circ} \mathrm{F}$., few fry until near high, 1019 at $70^{\circ} \mathrm{F}$. when fry are one per 40 feet vertical, one per 5 quarts and fifteen per minute towing, and of sizes 80 to 280

1 The name of the Greek symbol for "microns," is " mu." 
mu, with groups at $100,180,240 \mathrm{mu}$. August 21 , fry nearly fifty per minute, eight per 20 quarts, three per 10 feet vertical; sizes 80 to $320 \mathrm{mu}$, most are below $100 \mathrm{mu}$, a group at 180 , a few at 240 . August 25 , low ebb, nine to sixty fry per minute towing, five samples, thirty to forty in 20 quarts; sizes 80 to $380 \mathrm{mu}$, the majority are below $120 \mathrm{mu}$; groups at 140,180,200,240,280, and 320. August 28, fry are one per 4.5 feet vertical, of sizes 90 to $340 \mathrm{mu}$, majority at 140 .

Section below Cross creek, August 6, a few small fry present. August 14, 1020 at $70^{\circ} \mathrm{F}$., largest fry $120 \mathrm{mu}$. August 20 , high, $1019 \cdot 5$ at $67^{\circ} \mathrm{F}$., fry $80 \mathrm{mu}$ to 320 . Half ebb, 1020 at $70^{\circ} \mathrm{F}$., fry at rate of one per 4 feet vertical, one per 5 quarts, and two per minute of towing; sizes are $80 \mathrm{mu}$ to 220 . August 21, fry were found at rate of two to six per 20 quarts, below $200 \mathrm{mu}$ in size. August 28, fry at rate of three to nine per minute and one to 25 feet vertical, sizes are below $260 \mathrm{mu}$, mostly below $160 \mathrm{mu}$.

Section near ferry, August 14, 1020 at $69^{\circ} \mathrm{F}$., fry at rate of one per 12 feet vertical, under $200 \mathrm{mu}$. August 20, 1019 at $66^{\circ}$. F., few fry: at lower tide, 1019.5 at $68^{\circ} \mathrm{F}$., fry at rate of one per 4 feet vertical, and one per 7 quarts, grouped at $100 \mathrm{mu}, 200$, and 230 to $280 \mathrm{mu}$.

Grand River Cove: The roughness of water here prevented frequent observation. August $20,1019.5$ at $67^{\circ} \mathrm{F}$., in middle of cove, no fry. At cape Malpeque (Charles point) 1020.5 at $67^{\circ} \cdot 5 \mathrm{~F}$., fry at rate of one per 10 feet vertical, mostly small, one 200 mu. Avgust $21,1019.5$ at $70^{\circ} \mathrm{F}$., three fry per 20 quarts, largest $160 \mathrm{mu}$.

\section{UPPER BAY.}

With the upper bay, extending 7 miles southeast of Charles point, or south from Bunbury island, we shall include: (1) the "quadrangle" 4 miles north to south and 3 miles east and west, whose corners are designated, respectively, by Charles point, Bunbury island, Beech point, and Bentinck point; (2) a southern "head," 4 miles north and south, 5 miles east and west, which receives seven tributaries, that will be reviewed in circuit beginning on the northeast.

Oyster Creek: August $7,1018.5$ at $74^{\circ} \mathrm{F}$. Thirty quarts inside the grass area at its mouth, yielded four large $(160 \mathrm{mu})$ and many smaller fry. Outside the grass, the fry were few and small, and snail larvæ numerous. August 13, 1020 at $72^{\circ} \mathrm{F}$,, vertical sampling yielded a few small and one "large" (unequal umbos) fry in three hauls of 7 feet each.

Chichester Cove and Indian River: August 7,1019 at $73^{\circ} \mathrm{F}$., in cove, and 1016 at $74^{\circ} \mathrm{F}$, in the mouth of river. Snails numerous, oyster fry few and small, one "large" 1 found.

Barbara Weit River and Cove: August $7,1018.5$ at $72^{\circ} \mathrm{F}$. Many snails, few oyster fry. August $13,1018.5$ at $74^{\circ} \mathrm{F}$., samples yielded two large and a few small fry. Nearly all adult oysters have spawned, but some not.

Webber Creek Cove, or Waites Cove: August 7, many snails, few fry. August 13, ten hauls in 9 feet of water yielded two large, four medium, several small fry. August 24, twenty hauls of 5 feet each in 12 feet of water, yielded 33 fry, from 160 to $380 \mathrm{mu}$ in diameter, at ratio of one per 3 feet vertical, and quite satisfactory. Shells were put out as cultch here.

Plat River Cove: August 7, sample was poor in plankton, 1020 at $72^{\circ} \mathrm{F}$., in grass near cliff west of Webber point. Oyster fry more abundant towards Bentinck cove. August 13 , ten hauls vertical in 12 feet of water yielded five medium fry.

Shemody Creek and Bentinck Cove: August 7, in creek, 1015 at $74^{\circ} \mathrm{F}$., few oyster fry here. In cove, 1020 at $72^{\circ} \mathrm{F}$., oyster fry more abundant. August 13 , in mouth of creek, 1020 at $70^{\circ} \mathrm{F}$., sample shows but one large fry. In the cove, 1021 at $69^{\circ} .5 \mathrm{~F}$., vertical sample in 5 feet of water yielded three large and three medium. Farther out, in 10 feet of water, vertical sampling yielded a larva of $240 \mathrm{mu}$.

1 We use the general designation of "large" for fry with unequal umbos, "medium" for those with prominent equal umbos, and "small" for those less than 100 mu in length. 


\section{SESSIONAL PAPER No. 38a}

"Head" of Upper Bay: August 7, sample near Bentinck point was poor in fry. In the middle of the bay the water was 1020 at $74^{\circ} \mathrm{F}$. Each of two samples contained a fry nearly ready to "set." August 24 , on high water, 1020 at $68^{\circ}$ F., a long course, dipping from Beech point towards Webbers point, yielded but few fry, the largest was $240 \mathrm{mu}$.

The quadrangle west of Curtain Shoals: August 7, in its southern portion three samples showed many snails but no oyster fry. Farther north it was much the same story, only one large fry found in four samples, but many snails.

Commentary on Upper Bay: The considerable distance of this part of Richmond bay from our base at Malpeque, combined with the roughness of the "quadrangle," prevented as full a study of this part as was desirable. Once we buffeted the waves quite to Bentinck cove and were compelled to return to shelter east of Curtain shoals. This sort of work cannot be done on a boat pitching extremely. From the data secured, it is indicated that the oyster plankton of the open bay is sparse, and that it is only close to the broad flats that line the shores, where the oyster plankton li as fairly abundant. There seems to be some correspondence between water temperature and oyster plankton, more being found in the warmer waters than the colder ones. Another point to be noticed is that the water on the shore flats, probably never leaves the upper bay on the ebb tide, but retires temporarily to the edge of the flats to return on high water, and so the contained oyster plankton is not lost from this cause. This is on the supposition that the fry do not themselves have habits that would oppose their transport outwards on ebb tides. While this question is still under investigation there is strong evidence to show that fry are more abundant at the surface on flow than on ebb.

Another interesting point concerns the snail larvæ. These were extraordinarily abundant in the Upper bay. The flats of the Upper bay are extensively covered with grass. We found snails more abundant near grass plots in all parts of Richmond bay. We do not know whether the snails feed on the oyster fry, but have suspicions. This matter is worth investigating. We know that snails are enemies of the young spat. It is probable that these snails should be fought in the interest of oyster culture.

\section{MARCH WATER.}

This part of the bay is bounded on the southwest by Curtain islands and Beech point." Across the shoals between the point and the islands, there is current communication with the "quadrangle" and with the Upper bay. March water is bounded on the northeast by Prince point and "Ram" island. Across these shoals, therc is water communication with the Lower bay. But the main outlet is to the northwest, between Bunbury and Ram island, into the Central bay. The eastern part of the March water section is the Shipyard basin, at whose head is Malpeque wharf. Shipyard river enters here from the south. Shipyard basin is separated from March water by a considerable grass flat. Extensive grass flats also cover the Curtain Island shoals. The oyster beds are mainly near Prince point, Ram island, north of Bunbury shoals, and the channel between Bunbury and Ram island. Owing to the fact that our home base was at Malpeque, and also that we had to traverse March water every -ime a visit was made to any other part of the bay, and that it was less disturbed by winds than other parts, this section received more continuous attention than the rest of the bay. It did not, however, offer so rich a plankton as did Grand river between Southwest creek and Cross creek. We shall consider our observation of it as a whole, chronologically.

August 5, at low ebb, on "old dump" in northern part of Shipyard basin, 1020 at $70^{\circ} \mathrm{F}$. A dipped sample yields many snails; Peridinias and Tintinnias, a few large oyster fry, some medium, and several small ones. Similar results found after crossing the grass. On Princetown beds the snails were fewer, oysters more numerous, but still $38 \mathrm{a}-5$ 
few as compared to the numbers familiar in our New Jersey studies. The mussel and clam larvæ were more numerous, and of more kinds than in Barnegat bay, N.J.

August 6: Three samples were dipped in the "basin," with results like those of yesterday. Samples taken after passing grass, between Ram and Curtain islands and at junction with the Central bay show few small or medium oysters, none large, many other bivalve larvæ and snails. Samples were again taken on return from Bideford and Grand rivers in evening, but labels were lost.

August 7: Shipyard basin, before reaching the grass, one sample shows one large and one medium fry, and few small ones. After passing the grass, sample yielded five medium fry under $120 \mathrm{mu}$. Returning in the evening from trip to Upper bay, a sample taken between Ram and Bunbury islands, was nearly all snails; a sample near the grass had many snails, and a few oyster fry. In the Shipyard basin a sample yielded many small oyster fry.

August 9: Rainy, tide high. In the channel opposite the break between Iittle and Big Curtain islands, compared vertical samples with dipping from the surface. The surface was 1021 at $67^{\circ} \mathrm{F}$., and yielded one large and one medium, in 20 quarts, and a fair show of small fry. The bottom 1021 at $68^{\circ} \mathrm{F}$., yielded three medium, and some small fry and lots of sand. Next the surface was sampled, using 20 quarts in alternation with vertical "hauling" in the three uppermost feet, nine samples. Thirty feet of vertical sampling nearly balanced 20 quarts of surface dipping. No fry larger than $120 \mathrm{mu}$ were found, and never more than one or two; small fry were present in small numbers.

August 10: Compared dipping with vertical sampling from bottom to top. In 20 feet of water between Bunbury and Ram, and Prince to Beech points, hauled net, and dipped 30 quarts from surface, 14 samples. Obtained two fry of 200 and $260 \mathrm{mu}$, three to six medium; and several small ones. Found four species of three genera of Peridinidæ, viz., Ceratium tripos, C. divergens, Dinophysis acuta, and Peridinia sp? Also many Tintinnus suibulatus.

August 11: High water, and strong northeast wind. An oyster secured by dredging in channel is filled with immature spawn. Water 1021 at $66^{\circ} \mathrm{F}$. Shells obtained by dredging hold no spat except "deckers" and barnacles. Samples of 30 quarts yield each two large fry and two medium ones. Vertical sampling secured one large fry per 20 feet; also some medium.

Augutst 12, a sample dipped near Bunbury yielded one medium, and two smaller fry. Oysters from Ram Island point are nearly through spawning. Hung out shell cultch on buoy nearest wharf, and sampled water here, finding one large and two medium fry in 20 quarts.

August 14, in channel between Ram island and Little Curtain island, water is 1019.5 at $68^{\circ} \mathrm{F}$., vertical sample gives one fry per 14 feet, the largest being $200 \mathrm{mu}$, but most are $120 \mathrm{mu}$. In Shipyard basin, at the buoy farthest from wharf, water is 1019.5 at $70^{\circ} \mathrm{F}$., and vertical sampling yields one fry per $12 \mathrm{feet}$; one is $360 \mathrm{mu}$, or nearly ready to set, one is $200 \mathrm{mu}$, seven are $120 \mathrm{mu}$. At buoy nearest wharf, vertical sample gives one per 30 feet, with largest larva $160 \mathrm{mu}$.

August 16, rainy. Made a survey of March Water section, at same time compared methods of taking fry. Used vertical sampler for surface towing, as well as for deep sampling. Between Ram and Bunbury, secured fry of sizes 80, 100, 160, 200, $280 \mathrm{mu}$. In line of Beech point and Ram island, vertical sampling yielded one per 30 feet of sizes $80,120,160 \mathrm{mu}$. In line of Beech point and Prince point, vertical sampling gave one per 20 feet of sizes 160, 240,-340 mu. Towing towards Princetown beds yielded fry up to $180 \mathrm{mu}$. On Princetown beds, vertical sampling yielded one per 15 feet, of sizes 110 to $120 \mathrm{mu}, 160,240,320$, and $400 \mathrm{mu}$, which last is the largest seen, and also represents the largest after "setting." A second sample towards Grog island gave similar results, both in ratios and sizes. A towing sample yielded six large fry per minute, the leading groups being at 160, 240, and $340 \mathrm{mu}$. Small fry being quite difficult to separate from small larvæ of other bivalves, were generally not counted fully. 


\section{SESSIONAL PAPER No. 38a}

Vertical sampling on the "dump" yielded one per 30 feet, the largest being $200 \mathrm{mu}$. Similarly, off Ramsey's, one per 25 . feet gave sizes 160, 220, and $380 \mathrm{mu}$. Towing towards the buoys farthest from the wharf, gave fry 180 to $240 \mathrm{mu}$. At this buoz a string of shells was hung as cultch; vertical sample here yielded one per 50 feet, of sizes 280 and $320 \mathrm{mu}$. Another sample at the buoy nearest the wharf gave same vertical ratio, but of size $160 \mathrm{mu}$ only. Towing towards wharf also gave fry of this size. Towing towards Shipyard river yielded no fry.

August 17, on way to Bideford, water on Little Curtain shoals was 1020 at $70^{\circ} \mathrm{F}$. Towing at full speed between Bunbury and Ram island, yields no fry, and we suspected that all were pressed through net. A northeast storm broke at 11 a.m., and weather did not clear until afternoon of the 19th. Meanwhile, we coated oyster shells with coal tar varnish for use as cultch.

August 20, compared 20 quarts dipped with one minute of towing. On "dump" no fry in either sample. On Princetown beds, fry were found only in towing sample, of size 140 to $200 \mathrm{mu}$. Further along channel no fry were found, nor all the way to Cross creek, in Grand river, a distance of 9 miles, and with one exception none were found in Grand river until the afternoon, when the flood tide came and there were plenty. This suggests that the fry had hidden in the bottom during the storm. On return, a pair of samples taken in March water between Ram and Bunbury islands, 1020 at $68^{\circ}$ F., yielded no oyster fry, though plenty of mussel larvæ were present.

August 21, tide ebbing all forenoon. Tarred shells were planted on Curtain Island shoals and Ram Island shoals. The afternoon was spent in Grand river.

August 23, too rough for sampling, tarred shells placed on Reilley's lot.

August 24, visited McNeill's lots off Waites point. Oysters there had finished spawning, and shells one week planted bore spat a millimeter (1000 $\mathrm{mu}$ ) in diameter. Tarred shells were hung out on these beds. A study of the spat on shells showed that the fry set between $320 \mathrm{mu}$ and $400 \mathrm{mu}$. For future studies of the spat see later the special section on "spatting."

August 26, cool and cloudy. Found water fresh and at $60^{\circ} \mathrm{F}$. at head of Shipyard river; near its mouth 1018.5 at $72^{\circ}$ F., high water. Worked in shelter of Bunbury island ("Big Curtain" island). Made study of methods and comparison of nets Nos. 12 and 20, in the channel, and secured most variable results: out of thirteen samples, two yielded no fry, the others yielded fry groups at 100, 120, 200,240, 280, 320, and $360 \mathrm{mu}$, at a rate of seven to twenty-four per minute, and one fry per 6 to 30 feet. Many spat show on shells on planted beds. Took up shells placed August 12 and August 16. No spat on latter; one-third of former bear spat.

$\Delta$ ugust 27 , cold northwest wind. Water at wharf 1019.5 at $66^{\circ} \mathrm{F}$. Took up tarred shells placed on Curtain and Ram Island shoals on the 21st, and also those planted August 23 on Reilley's lot. From Curtain shoals to Reilley's, water was 1020 at $68^{\circ} \mathrm{F}$, Secured nine samples en route, which were studied before being killed by formalin. We noticed action of the long proboscis-like foot of the mature fry.. The larva swims hinge down, with foot in front or dragging behind at will; used as a feeler to test surface for fixation. The fry secured, vielded sizes of 90 to 120, 160, 220 to 240,280 , 320 to $380 \mathrm{mu}$. Fewest are near the Reilley end of route.

August 28 , on Ram Island shoals, 1021 at $62^{\circ} \mathrm{F}$., a few fry below $160 \mathrm{mu}$ secured at rate of one per 30 feet. Fifteen quarts dipped had none.

\section{CENTRAL BAY.}

We next consider the northern or main section of the Central bay as it receives the ebb from the southern sections (viz., the quadrangle and March water), as well as that from Bideford and Grand river. We have noticed a decided falling-off in the number of fry as this portion is approached, so that we do not expect much from its survey. It has a considerable number of more or less depleted beds in its southern

$38 \mathrm{a}-5 \frac{1}{2}$ 
part, at the junction with the southern divisions, or in the neighbourhood of North Bunbury shoals, between the northern parts of the quadrangle and March Water section.

August 6, three samples taken on the way to Bideford river showed the presence of cyster fry, but none over $120 \mathrm{mu}$. South of Low point, 1021 at $70^{\circ} \mathrm{F}$., and on route to Grand river the same result was secured, and also from Grand river to March water.

August 7, the story of yesterday was repeated, and again on the 8th. The catch between the "Klondike" bed and North Bunbury shoals was mostly composed of snails. On August 10, at the west end of Horseshoe shoals, and therefore on the line of junction with the Lower bay, snails were few, but mussel and other bivalve larvæ most abundant; few oyster fry were observed; but so much sand was present as to render the examination difficult. On August 17, towing north of Bunbury en route to Bideford river yielded one fry $160 \mathrm{mu}$, on high water. Farther north, 1021.3 at $70^{\circ} \mathrm{F}$., a second fry of $160 \mathrm{mu}$ turned up, and a few smaller fry near Low point. Fry grew more abundant near the mouth of Bideford river. August 20 enroute to Grand river, six samples were taken from North Bunbury to half-way to cape Malpeque (Charles point) with water 1020 at $68^{\circ}$ F., and no fry were found. Next day, between Ram and Bunbury islands, at the entrance to March Water channel the same story was repeated. We may conclude, therefore, that the main stretch of Richmond bay proper is well depleted of oysters, and that the more abundant plankton of its estuaries and shores is not carried into it, to more than a slight extent.

\section{THE OUTER OR LOWER BAY.}

This division of Richmond bay is wide in the west, embracing the extensive Horseshoe shoals; and is narrow in the east, where the deep channel of Malpeque harbour leads out between Bill Hook island and Royalty point to the inlet. Farther east, Darnley basin connects from the south, between Royalty point and cape Aylesbury. Oyster beds are located north of the Horseshoe shoals, near Hog island, south, near Ram island, east, in the "harbour," and also at Montgomery point between Royalty point and Prince point.

August 5, samples taken near the beds of Ram Island point, and at the harbour, were crowded with mussel and other bivalve larvæ, among which was a small proportion of oyster larvæ, the largest being $165 \mathrm{mu}$; water 1020 at $68^{\circ} \mathrm{F}$. In Darnleg basin, 1021 at $70^{\circ} \mathrm{F}$., low flow, no oyster larra were found either near its outlet or near its head; but an enormous number of Peridinias were present. August 10, strong east wind blowing against a strong out-going tide, between Forseshec shoals and Ram island, one frv $120 \mathrm{mu}$, apoeared. and several smaller ones in 30 quarts. Vertical sampling of a total of 30 feet, showed fewer fry, but more silt. In the harbour, a comparison by dipper sampling, with vertical sampling, showed so much sand that the determination of the fry was unsatisfactory; so far as the evidence went, it showed the presence of fewer fry than farther up the bay. North of the shoals, towards Hog island, the samples doubtfully contained oyster fry, but were crowded with Peridinias; west of the shoals, a few fry less than $120 \mathrm{mu}$ were found. August 28, at Montgomery point, vertical sample showed a ratio of one fry per 15 feet, mainly small, but sizes 320 and $360 \mathrm{mu}$ were also present.

Commentary: Our samples of this, and of the Central divisions of the bay, except March water, were not so numerous as they should have been to form definite conclusions. These parts of the bay are specially difficult of study, except in calm weather, at which time conditions are also extra favourable for study of regions richer in fry. Enough has been learned to make it reasonably certain that oyster fry were abundant in proportion to the distance from the outlet, and we believe this is due to at least three causes: (1) loss by ebb tides; (2) coldness of water near the inlet; (3) fewer oysters. Even when the oyster beds nearest the central and lower divisions of the bay were in their original full vigour, we believe that they were maintained with a narrower margin of survival than those farther away. Under the circumstances, it has been easier to deplete them, and will be correspondingly more difficult to restore them. 
SESSIONAL PAPER No. 38a

SUMMARY OF THE DISTRIBUTION OF OYSTER FRY.

The yield from 20 quarts dipped was one to four fry in Bideford river, one to forty fry in Grand river, one to three fry in Upper bay, two to five fry in March water. One minute's towing vielded 2 to 166 fry in Grand river, and seven to twenty-four fry in March water. Vertical sampling yielded one fry in 15 to 60 feet in Bideford river, one to 40 feet (with majority at two to 6 feet) in Grand river, one to 24 feet. (average at $10 \mathrm{feet}$ ) in Upper bay, and six to 50 feet (average $25 \mathrm{feet}$ ) in March water. Grand river leads, with March water and Cpper bay struggling for second place. Our highest record of two fry per quart sinks into insignificance, when compared with the several hundreds per quart with which we have been accustomed to deal in our New Jersey oyster investigations.

TABLE summarizing the sizes, in microns, of oyster larvæ, August 5-28.

\begin{tabular}{|c|c|c|c|c|c|c|c|c|c|c|c|c|c|c|}
\hline - & Aug. 5 & 6 & 10 & 13 & 14 & 16 & 17 & 20 & 21 & 24 & 25 & 26 & 27 & 28 \\
\hline $\begin{array}{l}\text { Stages . } \\
\text { I....... }\end{array}$ & * & * & * & * & * & ${ }^{*} 80$ & * & $\begin{array}{l}70 \\
80\end{array}$ & $\stackrel{*}{80}$ & $\begin{array}{l}* * \\
*\end{array}$ & $\begin{array}{c}* \\
\cdot 80\end{array}$ & * & * & $*$ \\
\hline Trans..... & * & * & * & * & * & $*$ & * & 90 & * & * & * & $*$ & 90 & 90 \\
\hline II. & $\begin{array}{l}* \\
110 \\
-\end{array}$ & E & $\begin{array}{c}* \\
- \\
120\end{array}$ & $\begin{array}{l}* \\
\text { - } \\
\end{array}$ & $\frac{*}{120}$ & $\begin{array}{l}100 \\
110 \\
120\end{array}$ & $\overline{-}$ & $\begin{array}{l}100 \\
* \\
*\end{array}$ & $\begin{array}{l}100 \\
110 \\
*\end{array}$ & E & $\begin{array}{l}* \\
* \\
120 \\
\end{array}$ & $\begin{array}{l}100 \\
110 \\
120 \\
\end{array}$ & $\begin{array}{l}* \\
* \\
120 \\
\end{array}$ & $\begin{array}{l}100 \\
* \\
*\end{array}$ \\
\hline Trans. & 一 & - & - & - & - & - & - & 140 & $*$ & - & 140 & - & - & 140 \\
\hline III. & $\begin{array}{l}160 \\
-\end{array}$ & $=$ & $\bar{z}$ & $=$ & $\begin{array}{c}160 \\
-200\end{array}$ & $\begin{array}{l}160 \\
180 \\
200\end{array}$ & $\begin{array}{l}160 \\
180 \\
200\end{array}$ & $\begin{array}{l}* \\
180 \\
200\end{array}$ & $\begin{array}{l}160 \\
180 \\
200\end{array}$ & $\begin{array}{l}160 \\
* \\
*\end{array}$ & $\begin{array}{l}160 \\
180 \\
200\end{array}$ & $\begin{array}{l}- \\
- \\
200\end{array}$ & $\begin{array}{l}160 \\
-\end{array}$ & $\begin{array}{l}160 \\
* \\
*\end{array}$ \\
\hline Trans..... & - & - & * & - & - & 220 & * & 220 & * & * & $*$ & - & 220 & * \\
\hline IV. & I & 二 & $\begin{array}{l}* \\
260 \\
-\end{array}$ & $\begin{array}{l}240 \\
-\end{array}$ & $=$ & $\frac{240}{280}$ & $\begin{array}{l}* \\
260 \\
*\end{array}$ & $\begin{array}{l}240 \\
* \\
280\end{array}$ & $\begin{array}{l}240 \\
* \\
*\end{array}$ & $\begin{array}{l}240 \\
* \\
*\end{array}$ & $\begin{array}{l}240 \\
* \\
280\end{array}$ & $\begin{array}{r}240 \\
-\quad 280 \\
\end{array}$ & $\begin{array}{r}240 \\
\hdashline 280\end{array}$ & $\begin{array}{l}* \\
260 \\
280\end{array}$ \\
\hline Trans..... & - & - & - & - & 320 & 320 & * & 320 & 320 & 320 & 320 & 320 & 320 & 320 \\
\hline$V$ & - & E & - & 二 & $\begin{array}{l}\overline{3} 60 \\
-\end{array}$ & $\begin{array}{c}340 \\
-380 \\
400\end{array}$ & $\begin{array}{l}* \\
360 \\
380 \\
400\end{array}$ & $\begin{array}{l}* \\
360 \\
-\end{array}$ & E & $\begin{array}{l}* \\
* \\
380 \\
400\end{array}$ & $\begin{array}{l}340 \\
* \\
380 \\
-\end{array}$ & $\begin{array}{l}-360 \\
-\end{array}$ & $\begin{array}{l}* \\
* \\
380 \\
-\end{array}$ & $\begin{array}{l}* \\
360 \\
380 \\
-\end{array}$ \\
\hline
\end{tabular}

The preceding table of sizes must not be interpreted without a clear understanding that it represents a summary of the records, and only roughly a summary of the actual facts. The records, as compared with the facts, are incomplete, fragmentary, and approximate. They are incomplete in that a careful correlation of sizes and temperatures was not made, or where made, the data have not been worked into the table; also incomplete, because the relative proportions of fry at the different sizes. though secured in a large number of our observations, have not been incorporated. This because of the misleading conclusions that would be derived from such a collation, in the absence of temperature relations, sufficiently complete to be of scientific value. The records are fragmentary, in that it was impossible to secure full data from all the areas, and we wished to cover all the area even though it had to be done at the sacrifice of completeness. The sizes are approximate, in that we purposely used a low-power microscope and a micrometer with coarse divisions, for the sake of

\footnotetext{
*Sizes noticed but not counted. Stages are: I., straight hinge stage, or "small"; II., equal umbos, or "medium"; III. and IV., unequal umbos, or "large"; V., ready to set as spat. New Jersey oyster larva set in stage IV., Canadian in Stage V. "Trans" means transition from one stage to next.
} 
expedition, judging by the eye of the fractions. No accuracy beyond 10 microns was possible, and we rarely strove for an accuracy beyond 20 microns. Thus all our measurements fall into groups separated by 20 microns, which gives the false impression that the fry were produced in corresponding broods. There is no doubt that broods do exist, but it is necessary that the entire attention be "focused on this aspect of things, in crder properly to establish the number and sizes of the respective broods. We had to choose between covering a small field of observation thoroughly and accurately, or the reverse; and we deliberately chose the latter alternative, as the logical thing to do, beginning with the general and specializing on such parts as the general survey showed to be worthy of additional work. Of course, a complete uncovering of oyster biology cannot be expected in one month or one season, henee the finer work remains yet to be done.

But the table does indicate some things of practical value, and that is why it is introduced. It will be noticed that fry, ready to set, were not observed in fair abundance until August 16. Indeed, the largest recorded for the 5th, 10th, 14th, and 16th, represents a regular advance in growth of 240 microns in twelve days, or 20 microns per day, which gives seventeen days as the minimum length of life of the floating larvæ. This length of life is quite to be expected under the influence of the higher range of temperature, 72 to 74 degrees, recorded. But a large proportion of the fry exist in temperature averages of less. than 70 degrees; and there is independent evidence ${ }^{1}$ showing that the period of free life of the fry in Richmond bay is over three weeks. It is not unreasonable to suppose that some of the fry may grow even slower than this rate. The rough survey marks out the boundaries of special problems that call for more accurate researches, on the rate of growth. Another feature indicated by the table, is the distribution of spawning. Spawning began late in July or early August, and was practically continuous thronghout the greater part of August, with a climax at the 20th. Not only does an individual oyster use a considerable period for ejecting its spawn, but the individuals on a bed do not mature at the same time. Further, it is evident that as the oyster beds of the bay are subjected to different ranges of temperature, the different beds do not propagate simultaneously. It follows, therefore, that spatting is also a more or less drawn-out affair, although there are special favourite days for spatting as for spawning, dependent on weather, as shown by our New Jersey researches. These researches also have shown that not all the broods of fry that appear successively, reach the spatting stage successfully. This is another problem demanding research. The practical aspect of this question lies in the fact that cultch, to be most useful, must be clean, and to be clean must be placed closest to spatting periods. It follows that cultch planting should be periodic, and that the periods should be regulated by the general weather and special plankton reports of the locality proposed to be shelled. For further discussion of spawning and spatting see those sections farther on.

\section{TEMPERATURE SUMMARY.}

Temperature is a factor of supreme importance in oyster life. The warmth of the water depends on depth, character of bottom, distance from inlet, direction of winds, temperature of the air, and on the sunshine. The highest temperature was $76^{\circ} \mathrm{F}$., observed once on the flats off Tilton creek; but $74^{\circ} \mathrm{F}$., was found at the head of Bideford river, in Shemody creek, in Indian river, in the head of the bay, in Oyster creek, in Barbara Weit river, part of the time at Grand River bridge, and near Southwest Creek bridge. This is only 6 degrees above the minimum for oyster propagation, and the main areas of Richmond bay fail to reach this maximum. Thus, 72 degrees was recorded in the upper Grand river, Trout river, Bideford river, off Plat river, lower part of Shemody creek, and off Barbara Weit river, Oyster creek, and the mouth of

1 See Stafford. "The Canadian Oyster," 1913 , pp. 83 and 84 . This excelient memoir is a very full exposition of the biology of the oyster. 


\section{SESSIONAL PAPER No. 38 a}

Shipyard river. Seventy degrees was recorded for Shipyard basin, Darnley basin, Narrows, Bideford river, Shemody creek, Grand river, March water, Curtain Island flats, etc. This figure was recorded more often than any other, but $68^{\circ} \mathrm{F}$. stands next in frequency, being recorded not only for the deeper and lower parts of the bay, as at the inlet, March water, head of Grand River cove, etc., but also from upper Grand river and Bideford river, after the cold winds and nights of the latter half of the month. There were eight instances of 66 to 67 degrees in March water and Grand river, after cold weather. August 28 the water at Ram Island shoals was 62 degrees. $\Delta t$ the head of Shipyard river, where the water was quite fresh, it was 60 degrees on the 25 th.

At best, the length of the season when the water in Richmond bay is warm enough for oyster propagation, is short, and when the warm weather of spring is delayed, as was the case in 1915, the spawning is shoved into August, and the spatting comes so late that the spat secure only slight growth before winter temperatures begin. The late spat of 1914 thus attained only a small size during the second summer of its existence. We found spat in August from Ram island, scarcely larger than one's little fingernail, that must have set the preceding fall.

A question arises here, to what extent may the oncoming cold of autumn interfere with the spatting of the late broods of fry which were the principal ones this year? In more southern waters we frequently get a set of spat in September, and even in October, and these have some chance to grow before winter. But there is quite likely a temperature limit, to spatting itself, which it is important to determine. The shallowness of a large part of Richmond bay, favouring rapid heating of the water, is also favourable to its quick cooling. If, therefore, the largest brood of fry should be prevented from setting, there is an additional obstacle to the rapid regeneration of oyster beds in Canadian waters. This also has favoured rapid depletion.

\section{SUMMARY OF DENSITY OBSERVATIONS.}

A great deal too much emphasis has been laid on the question of the saltness or density of the water in which oysters may be expected to flourish. Doubtless, the admixture, more or less periodically, of fresh water with the salt water, at the mouths of rivers, has a beneficial effect, but the range of salinity in which oysters will grow is so great that the careful observation of one or two points difference in reading on the scale of the salinometer, is of little practical, or possibly even scientific, value.

While salinity depends on distance from inlet, distance up rivers, the stage of tide, on wind strength and direction, and on rainfall, the variations and range of the readings of our salinometer were remarkably small. We found, in fact. almost the same readings as obtained at our New Jersey, Edge Cove, station. The highest record was 1021 found in Darnley basin, at half flood (August 6), in the Narrows at low, off Low point at half flood, in the channel of March water, both top and bottom, at high tide August 9 and 17, in Central bay, north of Bunbury, and in Ran Island shoals at high.

A reading of 1020 was most frequent, as in Shipyard basin, August 5, in Malpeque harbour at low, off Lennox island, and in the Narrows, off the mouth of Plat river, in Shemody creek (August 7 and 13), off. Tilton creek, and in the Upper bay, both at low (August 7 ) and high (August 24), in Oyster creek at half tide, at Grand River ferry on high, on Curtain Island shoals, and the mouth of Bideford river at high, and in March water at low (August 20 and 27).

Twenty observations gave 1019 and 1019.5 most frequently in the rivers or at the mouths of creeks. In Grand river, 1017, 1018 and 1018.5 were found not far distant from the bridge. This record was also given in Barbara Weit, Oyster creek, and Shipyard river. A reading of 1015.5 was observed well up Shemody creek at low 
7 GEORGE V, A. 1917

water, and 1016 in Indian river. The lowest, 1015, was recorded at the head of Trout river; the observation at the head of Shipyard river, which was the only river that was penetrated into the parts accessible only at high water, was exceptional. Here the salinometer read 1000 at $60^{\circ} \mathrm{F}$.

\section{SPAWNING.}

It was easier to ascertain the progress of spawning from examination of the plankton, than by dredging for oysters and opening the same. Dredging on natural beds did not bring up many oysters, and we depended on oysters from planted beds secured under direction of those in charge. An oyster secured in March water on the 11th was filled with immature spawn, but next day samples at Ram island showed that their spawning was completed. On the 13th in Bentinck cove we found that spawning was hardly half through, as half of the oysters had not begun, and the others were only partly spawned out. Near the Barbara Weit, on MeNeill's beds, however, only a few oysters contained spawn. On the 14th, in Grand river, half-way between Southwest creek and Cross creek, we again noticed that half of the oysters were still in full spawn; but near Cross creek, all that we secured were empty. Dredging for oysters near the ferry failed to secure any samples. On the 24th, on McNeill's beds, there were still traces of spawn. On the 26th, oysters in March water were through spawning. Owing to the small number of samples opened, and few observations, only general conclusions can be drawn from these observations, viz., that before the 20 th there was abundant spawn still present, and that after that date the oysters were nearly but not entirely through spawning.

Turning to the plankton record, we find that fry which were probably ten days old were present August 5, but oyster plankton was not abundant until August 14; and these fry were also about ten days old. On the 17th they were advanced to 200 microns, indicating an age of about two weeks. On the 20th, and especially on the 21st, small, lately hatched fry were most abundant. Here was a climax in the spawning, which probably occurred on the 20th, a fine day following stormy weather. On the 25th, fry under $100 \mathrm{mu}$ were scarce, but very abundant at that size, and not yet a week old. This day was a banner day for showing fry; they were abundant up to $320 \mathrm{mu}$. On the 26 th and 27 th there was an increase in the fry under $100 \mathrm{mu}$ in size, but these had attained $100 \mathrm{mu}$ on the 28 th.

\section{SPATTING.}

The study of spatting involves the determination of the date of "setting" (fixation of the fry to cultch as spat). Also a study of the rate of growth and of survival; also the determination of the most suitable cultch and localities and other conditions favourable to this process.

The date of spatting can be fixed by two independent sets of evidence: (1) observations on the presence and abundance of the largest fry "ready to set" in connection with the plankton data; (2) the "lifting" of the cultch, such as shells, from time to time, and giving them careful examination, after drying. Such shells should be specially selected, the cleanest obtainable, and preferably have been experimentally placed at set dates.

From the table given a few pages before, we learn that fry of spatting size (320 to $400 \mathrm{mu}$ ) were present in relative abundance from August 14 to 17 , and on the 24th and 27 th. These fry were not nearly so abundant as the fry seen previously, of sizes 260 to $320 \mathrm{mu}$. There was a reduction of at least 60 per cent. Part of this reduction may be explained as due to the probable presence of a certain number on the bottom seeking suitable cultch, so that the net necessarily failed to catch them. Part of the reduction was probably due to destruction.

When fry of 260 to $320 \mathrm{mu}$ are compared with earlier stages, we find also a reduction nearly as great, and while it is possible that the fry will remain on the bottom 


\section{SESSIONAL PAPER No. 38a}

more frequently as their shell grows larger, yet we are inclined to place the responsibility for the reduction upon destructive agencies. It must not be forgotten, however, that the number of fry secured from the water is not a true index of the number present, because a large proportion of every brood of fry will be found near the surface on fine days, and deeper down, or at the bottom in bad weather. Hence, the number is, to a good extent, an index of weather variations.

Although the water may show fry of spatting age, it does not always follow that a "set" will occur; if it did, the task of foretelling the date for placing cultch would be relatively a simple matter; this act seems to require fine weather. Much work needs to be done in this connection before we shall learn all we ought to know, in order to be of the best practical use, although what is already known can now be applied to advantage. From the table of fry sizes, it is evident that spatting was prophesied to occur from mid-August onward to the close of September, whenever conditions were favourable. It remains to study the cultch to fix those dates. We are not, however, in a position to state the exact date of. "setting" from a measurement of the spat until we know their rate of growth. This in turn cannot be learned except from a knowledge of dates of setting, determined independently. As much, if not most, of the spatting occurred after we departed, our data will not be complete; but shell samples sent us later throw some light on this question.

We have seen from the table that fry, ready to set, were not abundant until midAugust. Examination of cultch on the 11th and on the 13th, as well as other dates previous to mid-August, failed to reveal the presence of spat. Experimental cultch was suspended from a buoy near Malpeque wharf on the 12th, and on a buoy farthest from the wharf on the 16th, on Reilley's lots on the 23rd and on Curtain and Ram island shoals on the 21st. Part of the cultch consisted of plain, selected, hard shells, and partly of shells of a crumbly nature taken from weathered heaps of "mussel mud." Each of the latter shells was coated for two-thirds of its area from the broad end, with coaltar varnish. The object of the experiment, was to compare the relative efficiency of such a surface with the plain part of the cultch. Coaltar varnish was chosen because this is used to cover the bottoms of boats, and a boat was shown on which a fine catch of spat had fastened the previous season, thus suggesting that this paint was attractive to spat. It is easily understood why this boat carried such a set of spat. A bacterial slime will not form on the tar because of its antiseptic qualities; and other vegetable growths will likewise be prevented. Many of the spat of other animals, such as barnacles, might reasonably be supposed to avoid that surface, the coating being applied to boat bottoms to keep clear of such things.

There is, however, another factor to be considered as present in the case of the boat, which was not imitated with the tarred cultch. The hottom of the boat in the water is an "under" surface and not connected with the bottom. Being an under surface, no silt or sediment can settle upon it; and being unconnected to the bottom, the various crawling animals, snails, etc., would not be able to reach it and browse on its collection of spat. We note another fact of importance, viz., the paint was applied in the spring, several months before the spat set. Thus the tar had become thoroughly seasoned and hard, its soluble parts, creosotes, etc., that might be offensive to spat, had largely soaked out, when spatting began. In the case of our experimental cultch, only a few days' exposure to the water was admissible before the test occurred, and the tar was still soft where thickly applied.

The earliest spat observed were on shells taken on the 24th on McNeill's grounds, near Waites cove. Some of this cultch had been planted a week before, and some had lain a year on the beds. Several oysters were taken, and the outside of their shells was fairly well set with spat. The average spat was $1000 \mathrm{mu}$ in diameter (which equals a millimeter or one twenty-fifth of an inch). These, like all young spat, showed the larval shell of the size it was when setting occurred, and also the later added spat-shell. The larval shell ranged from 320 to $409 \mathrm{mu}$, and the spat shell 
7 GEORGE V, A. 1917

made a rim of $75 \mathrm{mu}$ around its edge. As most of the larva are $400 \mathrm{mu}$ high, from tip of left umbo to edge of right valve, it follows that spat growth can best be indicated by omitting this "constant" from the total measurement, which will henceforth be done.

August 26, the experimental shells which were placed on the 12th and the 16th, were taken for examination. No spat were found on the shells placed August 16, but a third of the shells placed August 12, carry spat up to a diameter of one millimeter. As no spat were found on the shells placed on the 16th, the inference would be that the spatting occurred before the 16th, which, taken in conjunction with the fact that these spat were of nearly the same size as those seen August 24, on shells planted for a week, leads us to the conclusion that in both cases we have to do with the setting of apat that showed as "ready to set" in the plankton of August 14. It might, however, not be true that the shells placed August 16 failed to catch spat, because all had set that were ready. Possibly none were in the water at that point, and this supposition becomes probable when we study the shells taken from the MeNutt bed, next to be considered.

Assuming the 14th as the probable date of first spatting, we get the tentative result of about $100 \mathrm{mu}$ growth of spat shell per day.

On the 26th we "lifted" several oysters and shells from the McNutt beds, and these showed spat very much like those in the McNeill samples. The most spat were found on the inside of oysters that had died and decomposed recently, leaving clean inside surfaces, well protected from entrance of both silt and the larger enemies, such as snails, because the valves of the oyster shell naturally separate only narrowly. A study of the distribution of these spat is instructive. The number of spat on the outside was equal for both valves; but totalled only one-eighth of the number found inside. There were twice as many inside spat on the right valve as on the left or lowermost valve, even in the instance where both valves were absolutely clean. The number was in all cases proportional to the cleanness of the surfaces, ranging for the inside upper valve from 1 to 150 spat per shell. The highest number was on a small shell, and the spat were most beautiful, showing what nature can do even with limited resources, if given a fair chance. We should also note that the spat prefer to set on the under side of an object, even when the surface is no cleaner or otherwise better than in other positions. The European oyster farmer takes advantage of the fact in his method of tile culture. In short, the spat like a "roof over foot." This is the result of natural selection, as those fry that possess the instinct to set under a surface, are not so apt to be smothered by silt, and also they find less silt to scrape away to get a hold.

The spat shells were measured in nearly fifty instances on the best set cultch sample and we found all stages present, from spat newly set, up to those having 1200 $\mathrm{mu}$ of spat-shell. Sizes 150, 400, and $600 \mathrm{mu}$ had the most numerous representation. Allowing $100 \mathrm{mu}$ growth per day, we get twelve days as the age of the oldest, which brings the date of beginning of spatting to be the 14th, quite in harmony with the plankton evidence. The main spatting period was from August 20 to the 22nd. This is in harmony with the figures in the plankton table for this period, showing few fry in stage $V$, because they were exploring the bottom at the time. As the climax of the spatting occurred on the 20th, and no spat were found on the shells placed on the 16th (taken on the 26th), it is evident that no fry ready to set were present at that locality. Still farther from the wharf were the Reilley experimental shells; they were placed on the 23rd and taken up on the 27 th, and no spat were present on them. So here, too, was an area which was poor in spat, at those dates at least. Just how far fry may wander from their birthplace, during the weeks of their plankton life, is not known, but it is a possibility that they do not wander far. This is a subject of great importance, and deserves careful research. While they are in the plankton condition they are a part of the water, and they use their swimming powers to rise or to sink. By rising into the tide early in flow, and settling to the bottom before ebb begins, it is evident they can wander as far from home as the distance travelled by a tide in six or seven hours. This would not distribute them laterally, to the current, except when 


\section{SESSIONAL PAPER No. 38a}

strong winds blow crosswise and they are at the surface, which is not usually true in rough weather. Everything depends on the adjustment they make in reference to the tides. We have found most fry on the flood tide. This would prove that the tendency is to work away from the inlet, and up towards headwaters.

On August 27, samples of tarred shells; placed on the 21st on Curtain island and Ram Island shoals were taken. Spat were found only on the Curtain island shells, on about six out of two dozen shells, and only from one to three spat per shell. The spat shell added, ranged in width from $160 \mathrm{mu}$ to $600 \mathrm{mu}$ during the six days' sojourn, thus corroborating our previous calculations. It is of course possible that the largest did not "set" at the earliest hour after planting, and so the growth might be greater than $100 \mathrm{mu}$ per day. This would not be surprising, since the conditions for growth are very good on these current-washed shoals. If the rings of growth seen correspond to diurnal additions, then one spat grew at the rate of $180 \mathrm{mu}$ per day. But it has yet to, be proved, that the growth of the dissoconch or any other shell growth, is adjusted to diurnal rather than tidal variations, or something else.

On September 3, Robert McKenzie took samples of shells from the McNutt beds, which were forwarded to me. Three of the seven shells sent carried spat; two "rights" held twenty and fifteen spat, respectively, and one "left" held six spat. This distribution suggests that they came from intact shells, for if the ralves had lain on the ground separately, the left valves would have carried the most spat. The appearance of the shells showed that they came from "cluckers" (i.e., oysters which, when tapped, sound empty). Two-thirds of the spat on these shells were newly set, and the oldest had a spat shell of $900 \mathrm{mu}$, which brings the date of their first setting not earlier than August 25. In harmony with this, our plankton table shows a considerable number of fry ready to set on the $24 \mathrm{th}$, with subsequent relative absence of this size. On this latter date also there was a great increase in younger stages, which probably furnished the spat that set September 2 to 5 .

On September 18, Hubert P. MeNeill took up and forwarded a string of tarred shells which we had placed on his beds on August 24, and also a large shell, which he wrote was planted August 30 . These samples proved highly interesting. Considering first the August 30 shell, this was a large left valve and remarkably clean after having been in the water for "eighteen days." It carried a small shell on its back with its smooth or inside surface facing in the same direction as the outside of the main shell, and occupying a seventh of its surface. The smooth inside of the large shell carried thirty-four spat, the outside eighty-nine spat, and the small shell thirtyeight. Had the small shell been absent, there should have been a hundred spat, or three times as many as on the inside; but if the entire surface had been as good as that of the little shell, there would have been 266 spat, or nearly eight times as many as on the inside. To account for this, we believe the shell hung with the curved side down. Had it rested on the ground, the spat would have been excluded from the center part of the convex surface. The sizes of the spat shells, viz., 40 to $560 \mathrm{mu}$, show that spatting had occurred within five or six days, so that there is a question as to its having been exposed for a longer period than a week. Turning now to consider the sizes of the spat shell-growth on the shells placed August 24, we have ranges of 0 to $2600 \mathrm{mu}$. As these shells were exposed twenty-five days, we have another fine coincidence on the basis of $100 \mathrm{mu}$ growth per day, assuming that setting began at once, which is probable, as the water at the place where the shells were hung had the finest show of fry, ready to set, seen in the entire bay. Granting this assumption, then there was spatting at this point on August 24, 28 and on Sepetmber 3, 5, 7, 8, 11, 16, and 18 , with climaxes on the 5 th and 15th. The latter climax fits the facts of the large shell lifted September 18, but leaves a mystery about the absence of fry on September 3 to 5 , if it was placed August 30, for the tarred shells corroborate the evidence of the McNutt shells. It must be carefully noted, that in all this calculation 
7 GEORGE $V$, A. 1917

the assumption is that the spat grow equally and similarly and uniformly, certainly rather unlikely. We need to have some careful research made on this problem.

Next let us consider the value of tar as a coating for oyster shells; does it improve shells to varnish them with coal tar? Striving to not crowd these pages with detailed tables, we shall give only the results of counting the spat. The figures show that per unit area, the tarred surface captured only two-fifths as many spat as did the invarnished shell; that the smooth side and rough side of the plain right valve were equal; that tarring reduced the number of outside spat to half, and those setting inside to a quarter as many as would have otherwise set. For the left valve, there was no difference between the plain and tarred surfaces outside, but a reduction to a fifth for the inside. The left valves caught more than twice as many spat as did the right valves. This was true respectively both for the plain and the tarred surfaces. We had long ago established similar ratios for these valves; yet we showed above that in "cluckers" lying in the normal position, it is the right valve that gathers most spat. The reason the left, free, valve and outside surface is superior to the right, is due to the fact that the silt fails to bury its edges as quickly as in the case of the flatter valve, when both are free.

The outcome of these researches is to suggest further studies with cultch coated with the composition (equal parts of lime, sand, cement) used for tiles in Europe. This is useful in view of the scarcity of cultch in Prince Edward Island.

October 4, Mr. McKenzie gathered samples from Ram island, placed there August 21. These shells held only "deckers" (Crepidulas). October 5, Mr. McKenzie gathered samples of Curtain island shells left there August 21, and therefore exposed for forty-five days. Two of them were tarred shells, carrying Crepidulas both on the tarred and the plain areas. The plain shells have but one spat on one surface (rarely on both). They range from 4 to 10 millimeters in diameter. Fragments of a Mya shell carry four spat of 16 to 20 millimeters in diameter. On the supposition that the largest had "set" as early as mid-August, they would be not more than fifty days old, and in the case of the largest spat, a growth of $400 \mathrm{mu}$ per day must have been attained on an average. Of course the growth is absolutely more rapid the older the spat, though it may relatively be less so. It is desirable to have careful studies made on growth, and we await with interest the results of Professor Robertson's researches on this subject.

\section{CONCLUSION.}

We have found that oyster propagation in Richmond bay shows the effects of the very considerable depletion indicated by statistics; but there are still areas, where careful planting of cultch will capture a fair set of spat. We wish to emphasize the necessity of pushing the practice of raising oysters from the seed, by artificial culture, insistently, persistently, consistently, and intelligently and scientifically, as the only way to restore the bay to its original productiveness, or even to keep its beds from ultimate destruction. But if the practice of scientific oyster culture be encouraged and developed, there is no reason for doubting that the maximum production formerly exhibited by this bay, under nature, and by fishing methods, can be increased very much. We do not think that every one of the 32,000 acres in this domain, can be made productive, but there is a good possibility that a quarter of this acreage may be made productive, and when that time arrives the annual product should be nearly a million bushels. It is worth while to strive for that figure, even if it may take a long while to reach it; by thus striving, it is certain that the present production will be increased many fold, to say nothing of conserving the very life of the oyster industry. If we go not forward we shall surely drift backward. 